\title{
THE FORMATION OF VALUE CONSCIOUSNESS OF STUDENTS IN POLYCULTURAL CONDITIONS OF PEDAGOGICAL UNIVERSITY
}

\author{
Iryna Barantsova, Aliona Rutkovska
}

Bohdan Khmelnytsky Melitopol State Pedagogical University

\begin{abstract}
Resume:
The article examines the impact of polycultural conditions on the formation of value consciousness in students. The author gives grounds for the idea that the practice of life in civil society, the functioning of its institutions is a relationship referring these or those values. It is proved that civil society is a place where college students can freely express their concerns, including proposals and strategies which have been developed by the government and administration of University; and the authorities can seek the opinion of students with specific issues; it is a place where the projects that imply students' participation both in them and other public organizations are developed, monitored and evaluated.
\end{abstract}

Key words:

values; education; civil society; polycultural conditions; student youth; value consciousness.
Анотація:

Баранцова Ірина, Рутковська Альона Формування ціннісної свідомості студентів у полікультурних умовах педагогічного університету.

У статті розглянуто вплив полікультурного середовища на формування ціннісної свідомості у студентів педагогічного університету. Показано, що практика життя в громадянському суспільстві, функціонування його інститутів - це взаємозв'язок, який спирається на ті чи інші цінності. Доведено, що громадянське суспільство - це місце, де студенти педагогічного університету можуть вільно висловлювати свої думки та погляди на пропозиції та стратегії, розроблені урядом та адміністрацією університету; місце, де влада може звертатися до студентів з конкретними питаннями; місце, де проєкти, що передбачають участь студентів у них, а також в інших громадських організаціях, розробляються, контролюються та оцінюються.

Ключові слова:

цінності; освіта; громадянське суспільство; полікультурне середовище; студентська молодь; ціннісна свідомість.
Аннотация:

Баранцова Ирина, Рутковская Алена Формирование ценностного сознания у студентов в поликультурных условиях педагогического университета.

В статье рассмотрено влияние поликультурной среды на формирование ценностного сознания студентов педагогического университета. Показано, что практика жизни в гражданском обществе, функционирование его институтов - это взаимосвязь, которая опирается нате или иные ценности. Доказано, что гражданское общество - это место, где студенты педагогического университета могут свободно выражать свои мысли и взгляды на предложения и стратегии, разработанные правительством и администрацией университета; место, где власти могут обращаться к студентам с конкретными вопросами; место, где проекты, предусматривающие участие студентов как в них, так и в других общественных организациях, разрабатываются, контролируются и оцениваются.

Ключевые слова:

ценности; образование; гражданское общество; поликультурная среда; студенческая молодежь; ценностное сознание.
Introduction. The emergence of civil society and its further development is a long way to create the preconditions for nurturing the values of civil society. Without changing the theoretical and socio-political stereotypes, without proposing qualitatively new ideas and approaches in theory, political and pedagogical practice, the solution of this problem is doomed to stagnation.

The theoretical conceptualisation of the values of civil society in the students' youth is closely linked to a wide range of tasks for the development of a democratic, social, rule of law. And it also requires the education of a person who has a high citizenship, national identity, a sense of patriotism, a political and legal culture. Insufficient level of absorption of values of civil society, skills of autonomy, freedom and culture of self-government is one of the reasons for alienation of a part of young people from sociopolitical and democratic processes in Ukrainian society.

Analysis of recent research and publications. The problem of influence of civil society values on the formation of personality consciousness was developed by V. Andrushchenko, V. Vasylenko, E. Golovakha, S. Krylov, V. Malakhov, V. Tabachkovsky and others.
As the post-Soviet period of life of Ukrainian society has shown, the transformation of the institutional foundations of the Ukrainian state, as such, is not a sufficient condition for the development of civil society and democracy. It takes a long process of transforming the value orientations of young people, educating students in a spirit of civic responsibility, tolerance, legal culture and justice.

In terms of the devastating impact on the minds of students of commercialized media and the Internet, which have immoral, anti-civic potential, education acquires the nature of spontaneous socialization, imitation of samples of mass culture, deviates from the normative system and manifests itself in social models, harmony in society (an anomaly by $\mathrm{E}$. Durkheim). As a socio-cultural community, student youth is a potentially intellectual and professional elite of the future society, and therefore the upbringing of its value orientations is of particular importance.

Acquaintance with the research materials makes it possible to assert that the student youth exhibits insufficient political activity, it has decreased readiness for "sacrifice", which is explained by the attitude towards a liberal type of society, which is 
characterized by the dominance of personal values over public [1, p. 68].

According to the author, differences in value orientations of different generations, mainly, "depend on the social and political situation in the country, the level of economic development, culture, morality, etc" [2].

A review of literature on the study of the value consciousness of modern students revealed a sharp devaluation of patriotic, heroic and altruistic behavior, devaluation in the public consciousness of social qualities, a sense of duty and responsibility, involvement in social and political processes taking place in society. There has been a pragmatization of the value consciousness of the younger generation and the rise in value of such values as wealth, material goods and pleasures, flat and expensive things, high-paying jobs, prestigious universities, careers and success at any cost.

Formulating the obectives of the article. The purpose of the article is to investigate the impact of civil society values on shaping the value consciousness of student youth.

Outline of the main research material. Market relations gave rise to the phenomenon of hypertrophied desire to have material benefits, not provided with an equal desire to create these benefits, which was manifested in the dehumanization and immorality of life directions. The content of the value consciousness of the modern student youth is determined by the peculiarities of the social, economic, political and cultural situation. It is characterized by the predominance of pragmatic and hedonistic values, which is the result of the dehumanization of the process of transition to the new socio-economic system, underestimation of the role of the moral foundations of social transformation.

Analysis of the pedagogical and psychological literature shows that the content of education is of value. Values determine the purpose and task of education - to form a value consciousness, value orientations. Therefore, to set a purpose of education means to determine the expected (desired) changes in the value consciousness of the pupil, which the teacher wants, and the criteria of education of the individual is a measure of absorption of values. Changing values leads to a change in the goals of education. Education is a purposeful activity in the formation or change of the outlook, sense and cultural-behavioral value system of the individual. Therefore, in the theory of education, the concept of "value" should be central.

Since the basis of social integration is the valuenormative system, the quality of civil society and the effectiveness of its institutions' interaction with the state are determined first and foremost by the valuesof civil society that dominate the minds of its members. Such values regulate the life of the individual in common with others, "which is necessary for the common social well-being and for the full development of people as individuals" [4, p. 173]. Everyday practice of life of civil society, functioning of its institutions are relations of these or those values. The essence and content of these relationships determine the values that are the fundamental values of civil society: human rights, freedom and autonomy of the individual, tolerance, patriotism and citizenship.

Civil society is a set of non-political relations (spiritual, moral, religious, cultural) and institutions, which is based on the principles of self-organization, activity and autonomy towards the state. As a system of institutions, relationships and values, civil society is a system of social ties in which the rights and freedoms, needs and interests of people are formed and realized. The meaning and importance of civil society can be defined as "the need for every mature person to participate in the creation of values that regulate their shared life with others, which is necessary for the overall social well-being and for the full development of people as individuals" [4, p. 173].

The education and formation of civil society values in student youth can be carried out under the influence of various public institutions - the family, higher education, and civil society institutions. The role of civil society institutions is difficult to overestimate here, because their work contributes to fostering mutual responsibility in the collective and acquiring the skills and abilities of the students to protect their personal interests, rights and freedoms.

The upbringing of civil society values in student youth, based on their awareness of their rights and responsibilities, is a process that involves the direct involvement of civil society institutions: educational institutions, professional, non-governmental organizations, the media, national-cultural and religious organizations. Civil society institutes are a place where student youth are free to express their concerns, in particular regarding proposals and strategies developed by the university's authorities and administration; give the opportunity to formulate their proposals, and the authorities - to find out the opinion of student youth on specific issues; this is a place where you can formulate your proposals; where projects that involve student youth not only in them but also in other civic organizations are developed, monitored and evaluated. Civil society institutions are called upon to make a significant contribution to the education of civil society students through formal and non-formal human rights education. The more developed the civic sphere, the stronger the social protection of each citizen from the arbitrariness of the state, the greater the opportunity for him to realize his creative powers. The less the state interferes with the 
regulation of public and personal life of people, the more developed is civil society. In this case, the citizen should be ready to "serve society against a state that is only something like a legal shell, with some external formality in the life of society" [5, p. 137].

The fundamental value of civil society is precisely human rights, since the purpose of civil society is to protect human rights and freedoms. Human rights and responsibilities are determined by the fact of his freedom, which "is the ontological basis of human life" (S. Frank). For example, the exercise of genuine citizens' freedom requires the autonomy of the individual from the state and society, but the absolutization of such autonomy is absurd.

Actions and behavior are determined by the level of individual freedom. Therefore, the most important task of nurturing the values of civil society in student youth is to nurture respect for human rights, which, in fact, means fostering a legal culture and shaping justice.

Legal awareness is the most important element of the legal culture, so the formation of justice is part of educating the legal culture. The task of fostering a legal culture is to promote respect for human dignity, human rights and freedoms, the formation of justice, the system of legal knowledge, skills, psychological attitudes to a positive attitude to law and relevant personal qualities that ensure legitimate activity and behavior. If culture is the result of material and spiritual human activity, then legal culture is the result of human material and spiritual activity in the sphere of law. Legal consciousness is a social, group and individual consciousness that reflects legal orientations, people's perceptions of the rightful and unlawful social order, related to the attitude to law, to social values, legality and justice. Still, Plato noted that "... the violation of the law causes precisely the harm that, gradually introduced, gradually penetrates into the outpost and skills, and from there, in larger sizes, extends to the business relations of citizens and encroaches on even the laws and the state system itself, moreover ... with the greatest distortion, and in the end turns everything upside down in both personal and public life" [6, p. 212].

Knowledge of their rights, freedoms and responsibilities, confidence in the need for their observance and implementation in practice are an indicator and criterion of the level of legal culture and the formation of justice in student youth. The legal culture is needed for students to properly (in accordance with the law) enter into legal relations, know their rights and responsibilities, be able to exercise them and, through legal mechanisms, effectively protect them. When performing these tasks, it is necessary to promote the student's selforganization, to develop his / her desire and ability to assert his / her rights and freedoms in public life, to form a tolerant attitude to another culture, to be able to engage in dialogue, to find compromises. Modern education requirements imply the ability of students to apply the opportunities of the legal system in the field of protection of rights and freedoms in a market economy. Therefore, the question of the legal culture and legal awareness of the student's personality becomes not only of academic importance, but above all practical.

Legal culture and justice is an understanding of the value of law in the regulation of public relations, the perception of legal norms as rules of compulsory behavior, the observance and application of the rules of law in accordance with the meaning laid down by law. The criteria for the formation of the legal culture and the student's consciousness are: legal awareness; value-oriented personality orientation; the perception of the law as of morally significant value; formation of legal skills and abilities regarding lawful, socially useful behavior, social and legal activity.

The process of educating the legal culture and shaping the students' justice should be considered as a coherent system in the interconnection of the most important elements: cognitive-rational (human rights education), emotional and activity-behavioral (involving students in legal activities and relationships). All of these components are interconnected and complementary.

An important aspect of legal culture is the promotion of tolerance in student youth.

The genesis of the concept of 'tolerance' (like other values of civil society) coincides with the emergence of civil society institutions in European countries and the formation of a free, autonomous personality. According to the 'Declaration of Principles of Tolerance" "tolerance means respect, acceptance and a correct understanding of the rich diversity of cultures of our world, our forms of expression and ways of expressing human individuality" [3]. The notion of tolerance in defining UNESCO means first and foremost an active attitude that is formed on the basis of the recognition of universal rights and fundamental freedoms. Tolerance is therefore a duty to promote human rights; in other words, a manifestation of tolerance, consonant with respect for human rights.

The content of our definition of tolerance is as follows: tolerance is an outlook, moral and psychological quality of an individual that enables him or her to accept or not adopt other social and cultural norms (identities) in the framework of respect for human rights. Accordingly, the basis for education in a spirit of tolerance is human rights teaching people what their rights and freedoms are, to secure these rights and to strive for the rights of others.

Our experience in national civilorganiztions shows that the most effective tool for fostering 
tolerance is the participation of young people in the work of civil society institutions. Working together in civil organizations with representatives of different cultures is a form of intercultural dialogue, during which the individual begins to understand the "other" and gradually recognizes his or her rights and freedoms. It is the dialogue itself, as a special form of interaction, that gives the subjects of communication the opportunity to overcome the internal discomfort of a different identity.

In modern conditions all the various external manifestations of the spiritual essence of a person are complicated by the lack of development of target objects, principles, potential of cultural-educational and pedagogical means of harmonizing the interaction of people, in which the first place is asserting the dialogic style of life of the subjects involved in cultural and educational space.

The dialogue, in our opinion, as a construct of understanding, is within the limits of constructivism to be the basis of the theoretical and methodological support of the spiritual development of a person.

Extremely important theoretical foundations for overcoming the contradictions in this process are studies in which the methodological ideas of dialogue as a way of being and dialogical understanding are substantiated (M. Bakhtin, V. Bibler, H. Gadamer, G. Dilthey, P. Rickor, F. Schleiermacher, etc.), which explore the problem of understanding in detail. The problem of dialogical understanding as a way of being, which leads to the spiritual growth of a man and the question of dialogical ontology, is disclosed in the writings of M. Buber, F. Rosenzweig, et al. The concept of "dialogical situation" and its essential characteristics were outlined by Y. Bogachinska, the implementation of the principles of dialogue in cultural and educational practices - by V. Bieberer, N. Bourbules, P. Kendzor and others.

Definition of the earlier nature of the dialogue, from a philosophical point of view, as an element of the theoretical, methodological, spiritual and ethical principles, in particular as a fundamental principle that is subjectively a fundamental requirement and a prerequisite for the thinking and behavior of the individual (maxim), and objectively leading the spiritual and practical norm of human co-existence [5, c.26], makes it possible to conclude that such a methodological guideline is not leading in existing cultural and educational practices that remain beyond the scope of dialogue, without the use of dialogue in the cultural and educational process.

In this way, its essential characteristics are not disclosed, and, therefore, the possibilities of influence on the cultural and educational situation to a large extent do not unfold. Moreover, if one or another of the dialogue remains beyond the actual problems of modernizing modern education and the "knowledge society", the general feature of which, according to S. Proletov, is “... a profound transformation of knowledge into various information constellations and the primacy of flexibility and speed of operation from information on conventional intellectual procedures and practices [1, c.7-24], then it cannot be considered a complete process of human spiritual development. Since the philosophers' postulate about the cultivation of a cultural person remains unchanged, the theoretical justification of the anthropological movement of a man from knowledge (in its broad substantive content as meaning) to the intellectualethical and spiritual interaction of the subjects of the world is needed.

It is also necessary to focus attention on the functional purpose of the dialogue, namely on its definition as a goal (deliberately chosen image of the intended result) and as a mechanism of transformation of the world that infinitely creates new goals (goal-setting). In this sense, it appears necessary to turn to the founders of the dialogue, Socrates and his followers, who unfolded the dialogue to its high degree of perfection on the basis of finding out the essence of one or another concept by means of questions and answers in which the main thing was not knowledge as such, but wisdom as a way of life, as its meaning (how to live, on what concepts).

Since that time, terminology and conceptual dialogue has changed, according to many scholars (M. Bulatov, V. Tancher, V. Andrushchenko, etc.), was enriched by L. Feuerbach, M. Buber, M. Bakhtin, K. Apel, J. Habermas (according to the latter within the framework of communicative ethics, the dialogue was understood as a discourse of a theoretical and analytical procedure, as a method of scientific analysis of a complex of problems with the accentuation of prudent, logical, conceptual elements and analysis tools, provided that they are supplemented by different approaches, interpretive insight, value correlation, rhetorical power, etc.).

However, as noted above, its original goals are: the content of dialogue as a form of dialectics, a means for defining concepts as a method of finding truth, which often remains beyond the comprehension of phenomena and is replaced by the analysis of many existential, practical actuals, etc. Therefore, remembering Socrates, who considered the dialectic to be worthy of the only human problem, its morals and, unlike the Sophists, who first laid the basis for the dialogue as a logical operation and a way of philosophizing and even the "middle" art of the birth of truth in human consciousness (Mayevics), his positions should be considered imperative.

It should be noted that in present conditions of the communication of different cultures, each of which is unique, without a "dialectical dialogue", as the prevention of the destruction of cultures in general, 
the absorption of certain cultures more technologically developed and, moreover, the promotion of the preservation of cultures and the enhancement of cultural heritage and the creation of a "cultural circle" is not possible. This has particular significance with regard to the dialogue that addresses spiritual values, which, in our opinion, has not yet been fully involved in a large-scale social dialogue and in cultural and educational process.

It is for this purpose that in the educational and cultural environment where there is a collision of various scientific, philosophical and religious discourses and where a certain continuum is born, such as the unity of institutions of education, science and culture, as the unification of the interests of various cultural identities, as the unification of personal, group and universal human positions, we should implement the idea of polydiscursivity. It suggests that perception of one or another phenomenon is possible only in the intersection of various communicative practices, and when the phenomenon of inter-religious, intercultural dialogue forms the basis for establishing multicultural stability, tolerant socialization of the individual, and the dialogue becomes in fact a polylogue and a way of finding, in our opinion, interculturalism.

In this sense, the fundamental question is the use of various discourses that have a certain social significance and specificity in dialogue, since "discourse" in scientific literature is defined as "linguistic activity regulated by socio-cultural codes (rules, traditions and values) of a particular social practice (science, justice, medicine, religion, politics, education, etc.), through which people - within the limits of this practice - produce, use and broadcast socio-cultural meanings, models of social experience, realize their own objective and / or communication needs" [6, c.37].

Thus, a scientific discourse aimed at an efficient process of creating, translating, and using knowledge and, in our opinion, until recently, according to its most active representatives, is most productive in finding the truth, because it implies: objectivity, installation in search truths, conceptuality (theoretical), empirical, logical, methodological, substantiation, critique and creativity.

At the same time the possibility and potential of a dialogue as a way of realizing individual subjectivity in cognition and activities, as well as algorithms of human movement from ignorance to understanding and comprehension of the metaphysical reality is not sufficiently grounded in science, although many thoughts and attitudes of today, which are based on dialogic universals of being and which should be assimilated by a person, in one form or another have already been considered in the past. In this sense, an important appeal to the philosophy that has presented the apodictic meaning of the phenomenon of "understanding" appears.

Polish professor E. Matinya writes that "... in society sometimes there is a protest, as well as a struggle with imposed forms of behavior ... these protests can be compared with the carnival, along with the temporarily sanctioned disagreements embedded therein. But, she says, "... this volatile sphere of community and dialogue plays a significant role in the emergence of a network of civic attitudes and the revival of the embryonic public sphere", and suggests several thoughts that can be transposed into social and religious practice: they should be viewed locally to the ground under their feet, to the places that each of us knows best, to places and narratives that have helped each of us overcome political and cultural separatism, reduce tension ...; one should learn the readiness to detolate the truth in the ecumenical approach; hospitality and generosity should be a key element of practice ... regardless of context; epistemologically it is necessary to pay attention to "knowledge with an accent", which can become for us the source of new plans and decisions of the problems of divided communities and societies; to bring to life the hospitality and openness that spread the dialogue in all its diversity, to embody them in the model of "civil architecture" - the agora as a place of "appearance" of a dialogue, a place where there are those who otherwise would never meet ..., but they (people) stayed here voluntarily" [6].

Thus, for the sake of the supremacy of a higher level of human interaction - understanding - and in order to prevent the era of silence, dialogue is precisely the "frontier", where there is a combination of fragmented parts of the consciousness of different cultures and identities, and where, on the basis of mutual understanding, the walls of identity are overcomed, the competences of their interweaving, the ethos of the border is popularized, and cities are presented between people of different cultures, religions and ethnic groups (colloquiums of dialogue, mobile academies of dialogue, "round tables", "word-café", religious festivals, etc.).

And finally, it should be noted that all previous analysis makes sense only if the dialogue needs to be learned and practiced in the cultural and educational space, which today is only in the stage of formation and which only begins as "full" subjects, to engage in religious practices. It is in this space that the scientific and vital knowledge, rational values and semantic orientations, education and culture, intentions and aspirations of the subjects of education, the goals, content and organizational and managerial technologies of the institutes of science, education, religion, culture should be in dialogue. and social life.

The conceptual ideas of fostering tolerance in a dialogue as a tolerant attitude towards a 
representative of another denomination are based on the following methodological approaches: the upbringing of religious tolerance should be carried out in the context of respect for human rights and freedoms (freedom of worldview and religion); in secular schools religious education should be nondenominational (in accordance with the constitutional principles of the secular state); religious identities must be counted against the priorities defined by the public majority (for the Ukrainian state, such priorities are national law, values of democracy and civil society).

One of the factors in the formation of tolerant relations in society is the upbringing of such values of civil society as civility and patriotism. An individual's citizenship is an awareness of his or her civil rights and responsibilities, encompassing civic qualities, evaluative and emotional attitudes toward civic manifestations, civic behavior and actions, as well as psychological attitudes to readiness for action, the will to realize it, and appropriate social needs. to form in the process of becoming a young person in the system of social institutions. Citizenship can manifest itself in legal, political, economic, professional and other types of socially significant activities. At the same time, a citizen's position does not necessarily have to express the interests of the public authorities. More often showing citizenship means opposing public authority. Citizenship expresses a high degree of influence of students on the solution of university, public and state problems. It may manifest itself in the practice of all-Ukrainian youth organizations as opposition activity on the official political course, in the process of which civic qualities and constructive proposals are formed.

Citizenship education is closely linked to the upbringing of patriotism. Patriotism is a special focus of self-realization and social behavior of citizens, the criteria of which are love and service of the Fatherland, ensuring the integrity and sovereignty of the state, its national security, sustainable development, duties and responsibilities, which give priority to the public and state bases over individual interests that make up the highest sense of life and activity of the individual, of all social groups of society. This understanding of patriotism enables us to view patriotism as a value of civil society, and patriotic education as a process of formation of a particular value consciousness and personality behavior, the content of which is the good of the country and the people.

The idea of patriotism has lately been subject to a thorough revision, down to the complete replacement of its meaning by political and religious ideologies. Today, patriots call themselves fascists, nationalists, radicals, fundamentalists. Quite often, patriotism is reduced to the ideas of nationalism, national exclusivity, the glorification of the achievements of the culture of any particular nation or nationality. For example, the main slogan of the youth All-Ukrainian public association of social-nationalists "Patriot of Ukraine" is "Nation above all". Such a statement is certainly incompatible with a sense of patriotism that must be matched by an understanding of the importance of the socio-political, legal, economic and cultural achievements of all peoples who inhabit Ukraine. Moreover, patriotic feelings and ideas only then ethically uplift people and nations when they are connected with respect for the peoples of other countries and are not transformed into the psychology of national exclusiveness.

In the system of education in general and patriotic education in particular, it is imperative to establish the boundaries of patriotism and nationalism, to clarify the content of national education and to address the pressing issue of ethos and nation, which we have tried to do in the study, based on the experience of other countries and authoritative comments and statements. In this sense, citizenship, as a value of civil society, is an obstacle to the formation of nationalist and xenophobic sentiments in young people.

Citizenship is the outlook of the person and the basis for the consolidation of society, which allows us to formulate a constructive ideology and to form civic positions of serving the Fatherland. Patriotic education is an important component of Ukraine's national security.

At the same time, patriotism for the society must become the core of value of citizenship, social ideal, the basis for guaranteeing the security of the country, preserving national identity and identity of the people. The state is powerful when citizens are committed to their homeland. Education of citizenship and patriotism as values of civil society encompasses intellectual, emotional, sensory and activity-behavioral components.

The value of citizenship and patriotism to civil society is manifested, first, in their political and legal foundations, whether consciously or unconsciously recognized by the majority; secondly, in the positive influence of these values on the spiritual world of a man (his worldview, morality); third, active behavior in all walks of life; fourth, to ensure the civic and patriotic solidarity of the people.

In higher education, patriotic and civic education can be facilitated by: contents of educational courses, forms of extracurricular activities (scientific societies, scientific student circles, clubs, conferences, olympiads, patriotic and civic actions, educational activities of patriotic and civic education, volunteer units, project activities, etc.).

The upbringing of civil society values in student youth, based on their awareness of their rights and responsibilities, is a process that involves the direct 
involvement of civil society institutions: educational institutions, professional, non-governmental organizations, mass media, national cultural and religious communities. organizations.

The effectiveness of nurturing the values of civil society depends on the regularity and systematic participation of students of higher education institutions in the activities of civil society institutions. Continuous participation contributes to the cultivation of mutual responsibility in the team and the acquisition of student skills and abilities to protect personal interests, rights and freedoms. Civil society institutions (eg student self-government bodies) should have direct action mechanisms, effective channels of dialogue, public scrutiny, communication and feedback.

Participation in the social practices of civil society institutions shapes the value consciousness of student youth in an epistemological dimension (broadening and refining knowledge of democracy, the rule of law, civil society and its values, human rights and freedoms, etc.), axiological (affirming values of democracy in the state, civil society, forming on the basis of value a positive attitude towards civil society and its institutions, a positive value attitude towards law as a civil society and democratic rule of law); in acmeological (promoting the development of civic activity, dynamism, indifference, civic, patriotic, political and legal maturity); in acting (direct participation in civil society institutions, formation of a culture of action, legal, tolerant, patriotic, civil behavior).

Summary.Thus, values of civil society (human rights, freedom and autonomy of the individual, tolerance, patriotism and citizenship) are a condition for the formation of value consciousness of the student youth and at the same time a means for the preparation of educated, moral, mobile, constructive and practical people, capable of cooperation, intercultural cooperation who have a deep sense of responsibility for the fate of the country, its socioeconomic prosperity. Prospects for further research are to study the characteristics of modern students as a resource for the restoration of the intelligentsia, capable of further developing the value consciousness of society.

1. Vishnevsky Yu. R. (1997). The Social Image of Studenthood of the 90s, Sociological Research. № 10. PP. 7-69 [in Russian].

2. Gonchar N. Valuable Consciousness of Ukrainian Students [Electronic resource], Access mode: http: //http://www/ji.lviv.ua/./n38texts/honchar-nat-htm.

3. Declaration of principles of tolerance [Electronic resource], Access mode: http://www.tolerance.ru/declar.html.

4. Dewey D. (2003). Reconstruction in philosophy. Human problems / trans. with English, after. and note, Moscow: Republic. 494 p. [in Russian].

5. General Sociology: Textbook/ under ed. of prof. A. Efendieva. M.: INFRA-M, 2004. 654 p. [in Russian].

6. Plato (1971). Works in 3 volumes / Plato; trans. with ancient Greek. under common. ed. of A. Loseva, V. Asmus. Volume 3. Part 1. Moscow. 687 p. [in Russian].

Рецензент: д-р філос. наук, професор Молодиченко В.В.

Information about the authors:
Barantsova Iryna Olexandrivna
irene25@list.ru
Bohdan Khmelnytsky Melitopol
State Pedagogical University
20 Hetmans'ka St., Melitopol,
Zaporizhzhia region, 72312, Ukraine

Rutkovska Aliona Mykhailivna

Bohdan Khmelnytsky Melitopol State Pedagogical University

20 Hetmans'ka St., Melitopol,

Zaporizhzhia region, 72312, Ukraine

doi: 10.33842/22195203/2019/23/16/22

\section{Список використаних джерел}

1. Вишневский Ю. Р. Социальный образ студенчества 90-х годов. Соииологические исследования. 1997. № 10. С. 7-69.

2. Гончар Н. Ціннісна свідомість украинского студентства. URL: http://www/ji.lviv.ua/./n38texts/honchar-nat-htm (дата звернення: 30. 08. 2019).

3. Декларация принципов толерантности. URL: http://www.tolerance.ru/declar.html (дата звернення: 30. 08. 2019).

4. Дьюи Дж. Реконструкция в философии. Человеческие проблемы / пер. с англ., послесл. и прим. Л. Е. Павловой. Москва: Республика, 2003. 494 с.

5. Общая социология: учебник / под ред. проф. А. Эфендиева. Москва: ИНФРА-М, 2004. 654 с.

6. Платон. Сочинения в 3-х т. / пер. с древнегреч., под общ. ред. А. Лосева и В. Асмуса. Т. 3. Ч. 1. Москва: Мысль, 1971. 687 с. 